\title{
Gastric synovial sarcoma: a case report and literature review
}

\author{
HK Wong ${ }^{1}$, MB, BS, Simon Law ${ }^{1}$ *, MBBChir, FCSHK, Robert Collins ${ }^{2}$, MBBD (UNSW), FRCPA \\ ${ }^{1}$ Department of Surgery, Queen Mary Hospital, The University of Hong Kong, Pokfulam, Hong Kong \\ ${ }^{2}$ Department of Pathology, Hong Kong Sanatorium \& Hospital, Happy Valley, Hong Kong
}

Hong Kong Med J 2020;26:142-5

https://doi.org/10.12809/hkmj197986

\section{Case report}

A 54-year-old Caucasian man presented with dyspepsia for 5 months with mild loss of weight. Endoscopic examination showed a 2 -cm gastric ulcer with raised edges on the lesser curvature of the stomach. Endoscopic ultrasound demonstrated that the lesion involved the submucosa and muscularis propria, measuring $8 \mathrm{~mm}$ thick. Biopsy revealed, along with body-type mucosa, spindle cell tissue,

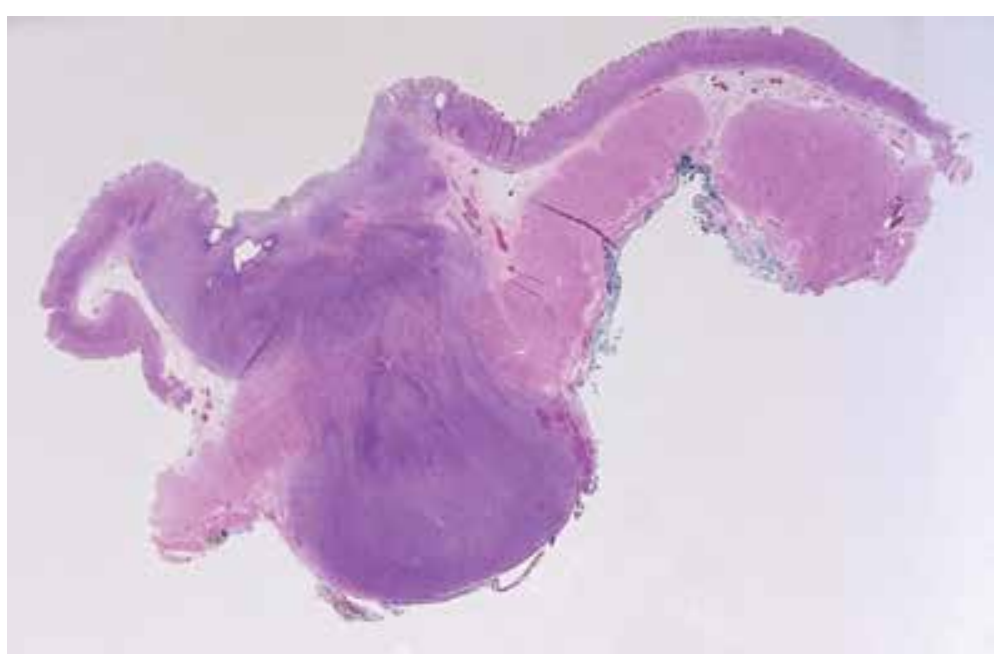

FIG I. Gastric synovial sarcoma on haematoxylin and eosin staining

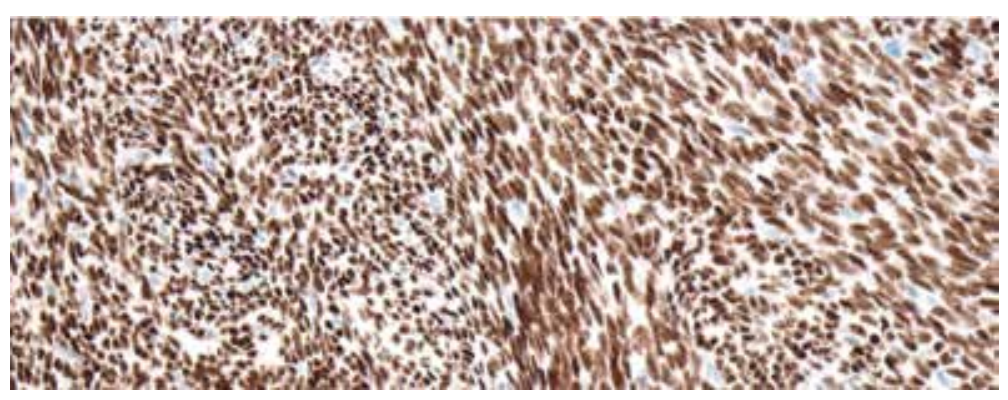

FIG 2. Immunohistochemical stain showing transducin-like enhancer of protein upregulation of the gastric synovial sarcoma $(\times 20)$
$2 \mathrm{~mm}$ in diameter. The cells had indistinct cytoplasm with elongated nuclei showing mild enlargement, and variation in size and shape. The initial comprehensive immunohistochemical staining panel (AE1/3, CAM5.2, c-KIT, CD34, DOG1, actin, desmin, STAT6, synaptophysin, HMB45, CD45, and calretinin) gave no positive results while the Ki67 index was $5 \%$ to $10 \%$. Computed tomography scan of the abdomen showed a 1.6- $\mathrm{cm}$ submucosal mass located at the gastric lesser curvature. There was no abnormal focal metabolic uptake in positron emission tomography scan. No hypermetabolic lymph node was found. The preoperative diagnosis was a submucosal spindle cell tumour.

Laparoscopic wedge resection of the gastric lesion was performed. Gross examination of the resected specimen showed gastric mucosa measuring $4 \mathrm{~cm} \times 3.5 \mathrm{~cm}$ with submucosal tissue of $1 \mathrm{~cm}$ thick. There was an ulcerated lesion measuring $0.7 \mathrm{~cm} \times 0.6 \mathrm{~cm}$ and $1.6 \mathrm{~cm}$ in maximal depth.

Microscopically, a dumbbell-shaped nodule was seen under the ulcer and extending through the muscularis propria to form a smooth nodule on the serosal aspect (Fig 1). Further immunohistochemical staining of the tumour cells was negative for cytokeratin (AE1/3, c-KIT, DOG1, CD31, CD34, desmin, actin, S-100, STAT6, ALK, calretinin, and HMB45. Ki-67 index was not high. The cells, however, showed positive staining for transducinlike enhancer protein 1 (TLE-1) upregulation (Fig 2) consistent with a diagnosis of synovial sarcoma and this was confirmed with fluorescence in situ hybridisation, which demonstrated a positive result for SS18 (synovial sarcoma) translocation. Six peritumoural lymph nodes and adjacent omentum showed no metastasis.

The patient recovered from his surgery without complications. He was followed up for 18 months after surgery with no signs of recurrence.

\section{Discussion}

Synovial sarcoma is a soft tissue sarcoma with common presentation in para-articular regions of the extremities although it is not related to synovium. It was first reported in 1893 and accounts 
for about $10 \%$ of all primary malignant soft tissue neoplasms. ${ }^{1,2}$ About $80 \%$ of synovial sarcomas are found in extremities, particularly the knee in the popliteal fossa, although they have also been reported in anatomical locations away from joints, including deep spaces in the head and neck, chest and abdominal wall, and visceral organs.,

Three histological subtypes of synovial sarcoma have been described: monophasic, biphasic, and poorly differentiated patterns. Monophasic synovial sarcoma is the most common subtype, in which the mesenchymal spindle cell component predominates. Biphasic synovial sarcoma has both a mesenchymal spindle cell component and an obvious epithelial component, representing $20 \%$ to $30 \%$ of synovial sarcomas. ${ }^{5,6}$ Poorly differentiated synovial sarcoma typically shows small round cell morphology and high mitotic activity, representing $15 \%$ to $25 \%$ of synovial sarcomas. ${ }^{7}$

Primary gastric synovial sarcomas are extremely rare, with only 31 cases reported in the English literature. Here we report a patient with primary gastric synovial sarcoma and published cases in the literature are reviewed.

Primary gastric synovial sarcoma is very rare, with the majority of malignant mesenchymal tumours in the stomach represented by malignant gastrointestinal stromal tumours (GISTs) and leiomyosarcoma. Synovial sarcoma has been reported to affect other parts of the gastrointestinal tract, including the oesophagus, duodenum, small bowel, ascending colon mesentery, liver, gastrocolic ligament, or omentum. However, the incidence of these tumours is very low, and few case reports are available in the literature. In 2000, Billings et $\mathrm{al}^{8}$ first reported two cases of primary synovial sarcoma in the gastroesophageal junction and stomach. In 2008, Makhlouf et $\mathrm{al}^{9}$ reported a series of 10 gastric synovial sarcomas, with mean age at diagnosis of 52 years. A recent published case was reported by Fuente et $\mathrm{al}^{10}$ in 2019 . The most commonly reported clinical presentations of gastric synovial sarcomas are epigastric pain and anaemia. ${ }^{11}$ A clinical summary of the 36 cases of primary gastric synovial sarcoma, including our case, is shown in the Table. ${ }^{8-10,12-23}$

When a gastric spindle cell tumour is encountered, the differential diagnosis mainly focuses on other gastrointestinal mesenchymal tumours, such as GIST, leiomyoma, leiomyosarcoma, schwannoma and fibromatosis. Appropriate immunohistochemical staining is crucial in order to make a diagnosis of synovial sarcoma. Although TLE- 1 is positive in the majority of synovial sarcomas, it is not specific for synovial sarcoma, as it can also be positive in other tumours such as endometrial stromal sarcoma, schwannoma, epithelioid sarcoma, solitary fibrous tumour, and rarely GISTs.

To confirm the diagnosis of synovial sarcoma, molecular analysis is essential. As many as 90\% of synovial sarcomas possess a fusion between the $S S 18$ gene on chromosome 18 and an SSX gene found on the $\mathrm{X}$ chromosome. ${ }^{11}$ This translocation, $\mathrm{t}(\mathrm{X} ; 18)$, can be reliably detected on formalin-fixed paraffinembedded tissue by polymerase chain reaction or fluorescence in situ hybridisation..$^{24,25}$

Optimal treatment for gastric synovial sarcoma is surgical resection. There is no evidence that lymph node dissection (as in gastric adenocarcinoma) will benefit. Our patient underwent laparoscopic wedge resection of the gastric tumour and had an uneventful recovery. After surgery, we did not administer chemotherapy or radiotherapy as the resection margins were clear.

From the literature, all recurrences or diseaserelated deaths in gastric synovial sarcomas occurred in tumours $>3 \mathrm{~cm}$ or those containing a poorly differentiated component; however, the prognosis of the disease is uncertain owing to the rare occurrence.

\section{Important points to note}

It is difficult to make a preoperative diagnosis of gastric synovial sarcoma based on endoscopic appearance only, as biopsies are usually negative. When sufficient tissue is obtained preoperatively, immunohistochemical staining can be applied. A panel of immunohistochemical stains should be utilised if the diagnosis is not apparent. When surgical resection is performed, the resected specimen should be saved for further evaluation.

When approaching a submucosal lesion identified on endoscopy with uncertain histological diagnosis, treatment usually is directed as if the lesion is a GIST, since this is most common. Local excision without lymphadenectomy is adequate, as in the current patient. Immunohistochemical staining and fluorescence in situ hybridisation are useful in differentiating gastric synovial sarcoma from other gastric spindle cell tumours.

The majority of recurrences in soft tissue sarcomas occur within the first 3 years of observation, and recurrence is rare in gastric synovial sarcoma. The assessment of recurrence risk, based on factors such as tumour grade and size, helps in determining a follow-up policy. According to the 2018 European Society for Medical Oncology Clinical Practice Guidelines $^{26}$ on soft tissue and visceral sarcomas, the following approach is recommended: follow-up of surgically treated intermediate- or high-grade patients every 3 to 4 months in the first 2 to 3 years, then twice a year up to the fifth year, and once a year thereafter; low-grade sarcoma patients may be followed for local relapse every 4 to 6 months, with chest X-rays or computer tomography scan at longer intervals in the first 3 to 5 years, then annually. ${ }^{26}$ However, gastric synovial sarcomas are so rare that reliable guidelines cannot be recommended. 
TABLE. Clinical feature of 34 gastric synovial sarcomas

\begin{tabular}{|c|c|c|c|c|c|c|c|}
\hline Case & $\begin{array}{l}\text { Age/ } \\
\text { sex }\end{array}$ & $\begin{array}{l}\text { Size } \\
\text { (cm) }\end{array}$ & Gastric involvement & Subtype & Type of surgery & $\begin{array}{l}\text { Adjuvant } \\
\text { treatment }\end{array}$ & Outcome \\
\hline $1^{8}$ & $47 / \mathrm{M}$ & 5.2 & $\begin{array}{l}\text { Gastroesophageal } \\
\text { junction }\end{array}$ & Biphasic & Partial gastrectomy & No & ANED, 21 months \\
\hline $2^{8}$ & $55 / F$ & 16 & Antrum & Monophasic & Hemigastrectomy & No & $\begin{array}{l}\text { Liver metastasis (at diagnosis), DOD, } \\
6 \text { months }\end{array}$ \\
\hline $3^{12}$ & $42 / \mathrm{M}$ & 11.5 & Posterior gastric wall & Biphasic & Tumour resection & Chemotherapy & $\begin{array}{l}\text { Mesenteric metastases, DOD, } 24 \\
\text { months }\end{array}$ \\
\hline $4^{9}$ & $67 / F$ & 0.8 & Body-antrum junction & Monophasic & Partial gastrectomy & No & ANED, 12 months \\
\hline $5^{9}$ & $49 / \mathrm{M}$ & 2 & Body & Monophasic & $\begin{array}{l}\text { Segmental/wedge } \\
\text { resection }\end{array}$ & No & Omental metastases, DOD, 29 months \\
\hline $6^{9}$ & $68 / F$ & 2 & Body & Monophasic & Wedge resection & No & ANED, 29 months \\
\hline $7^{9}$ & $29 / M$ & 2.8 & Body & Monophasic & Partial gastrectomy & No & ANED, 224 months \\
\hline $8^{9}$ & $54 / F$ & 3 & Antrum & Monophasic & $\begin{array}{l}\text { Antrectomy/ } \\
\text { gastroduodenal } \\
\text { resection }\end{array}$ & No & Follow-up case \\
\hline $9^{9}$ & $58 / F$ & 3 & Lesser-curvature/body & Monophasic & Wedge resection & No & ANED, 21 months \\
\hline $10^{9}$ & $37 / F$ & 4 & Fundus & Monophasic & Partial gastrectomy & No & Local recurrence, DOC, 48 months \\
\hline $11^{9}$ & $50 / \mathrm{M}$ & 6 & Distal fundus & Monophasic & Tumour resection & Chemotherapy & Recurrence, AWD, 6 months \\
\hline $12^{9}$ & $66 / F$ & 15 & Fundus & Monophasic & $\begin{array}{l}\text { Gastrectomy/partial } \\
\text { oesophagectomy }\end{array}$ & No & Lost to follow-up \\
\hline $13^{9}$ & $42 / \mathrm{M}$ & 8 & Greater curvature/body & Biphasic & Partial gastrectomy & Chemotherapy & DOD, 25 months \\
\hline $14^{13}$ & $38 / F$ & 7.5 & Body & Monophasic & Tumour resection & Chemotherapy & $\begin{array}{l}\text { Omental/hepatic metastases, } \\
\text { Recurrence in the liver, AWD, } 6 \text { months }\end{array}$ \\
\hline $15^{14}$ & $44 / F$ & 4.7 & Lesser curvature/body & Monophasic & $\begin{array}{l}\text { Laparotomy-wide } \\
\text { excision }\end{array}$ & $\mathrm{N} / \mathrm{A}$ & ANED, 60 months \\
\hline $16^{15}$ & $22 / \mathrm{M}$ & 2.5 & $\begin{array}{l}\text { Posterior mid-gastric } \\
\text { body }\end{array}$ & Monophasic & Wedge resection & No & $\mathrm{N} / \mathrm{A}$ \\
\hline $17^{16}$ & $42 / F$ & 3.5 & Body & Monophasic & Partial gastrectomy & No & ANED, 72 months \\
\hline $18^{17}$ & $44 / \mathrm{M}$ & 15 & Lesser curvature & Monophasic & Total gastrectomy & No & ANED, 18 months \\
\hline $19^{18}$ & $62 / M$ & 3.8 & Cardia and fundus & Monophasic & Total gastrectomy & No & ANED, 9 months \\
\hline $20^{19}$ & $50 / F$ & 8 & Body & Monophasic & $\mathrm{N} / \mathrm{A}$ & $\mathrm{N} / \mathrm{A}$ & $\mathrm{N} / \mathrm{A}$ \\
\hline $21^{19}$ & $36 / \mathrm{M}$ & 6 & Stomach & $\begin{array}{l}\text { Poorly } \\
\text { differentiated }\end{array}$ & $\mathrm{N} / \mathrm{A}$ & $\mathrm{N} / \mathrm{A}$ & AWD, 36 months \\
\hline $22^{19}$ & $37 / M$ & 6 & Stomach & Monophasic & $\mathrm{N} / \mathrm{A}$ & $\mathrm{N} / \mathrm{A}$ & $\mathrm{N} / \mathrm{A}$ \\
\hline $23^{19}$ & $26 / M$ & $\mathrm{~N} / \mathrm{A}$ & Stomach & Monophasic & $\mathrm{N} / \mathrm{A}$ & $\mathrm{N} / \mathrm{A}$ & AWD, 185 months \\
\hline $24^{19}$ & $58 / \mathrm{M}$ & 10 & Stomach & Monophasic & $\mathrm{N} / \mathrm{A}$ & $\mathrm{N} / \mathrm{A}$ & DOD, 6 months \\
\hline $25^{19}$ & $21 / \mathrm{M}$ & 10 & Stomach & Monophasic & $\mathrm{N} / \mathrm{A}$ & $\mathrm{N} / \mathrm{A}$ & ANED, 48 months \\
\hline $26^{19}$ & $36 / \mathrm{M}$ & 6 & Stomach & Biphasic & $\mathrm{N} / \mathrm{A}$ & $\mathrm{N} / \mathrm{A}$ & ANED, 48 months \\
\hline $27^{19}$ & $54 / F$ & 3.8 & Stomach & Monophasic & N/A & $\mathrm{N} / \mathrm{A}$ & $\mathrm{N} / \mathrm{A}$ \\
\hline $28^{19}$ & $49 / F$ & 3.5 & Stomach & Monophasic & Tumour resection & No & $\mathrm{N} / \mathrm{A}$ \\
\hline $29^{19}$ & $35 / F$ & 12 & Stomach & Monophasic & Tumour resection & Chemotherapy & Liver metastases, AWD, 48 months \\
\hline $30^{20}$ & $49 / F$ & 3.5 & Stomach & Monophasic & $\begin{array}{l}\text { Local surgical } \\
\text { excision }\end{array}$ & No & ANED, 10 months \\
\hline $31^{20}$ & $35 / F$ & 12 & Stomach & Monophasic & $\begin{array}{l}\text { Local surgical } \\
\text { excision }\end{array}$ & Yes & Liver metastases, AWD, 24 months \\
\hline $32^{21}$ & $51 / F$ & 1.7 & Body & Monophasic & Partial gastrectomy & No & ANED, 2 months \\
\hline $33^{22}$ & $58 / \mathrm{M}$ & 6.3 & Greater curvature/body & Monophasic & Wedge resection & $\mathrm{N} / \mathrm{A}$ & $\begin{array}{l}\text { Liver, peritoneal metastases, AWD, } 7 \\
\text { months }\end{array}$ \\
\hline $34^{23}$ & $57 / \mathrm{M}$ & 1.8 & Lesser curvature & Monophasic & Wedge resection & No & ANED \\
\hline $35^{10}$ & $42 / \mathrm{M}$ & 3 & Lesser Curvature & Monophasic & Tumour resection & No & ANED, 12 months \\
\hline 36 & $54 / \mathrm{M}$ & 1.6 & Lesser curvature & Monophasic & Wedge resection & No & Current case \\
\hline
\end{tabular}

Abbreviations: $\mathrm{ANED}=$ alive with no evidence of disease; $\mathrm{AWD}=$ alive with disease; $\mathrm{DOC}=$ died of other causes; $\mathrm{DOD}=$ died of disease; $\mathrm{N} / \mathrm{A}=$ not available 


\section{Conclusion}

Gastric synovial sarcoma is extremely rare, and diagnosis requires specific immunohistochemical and molecular analysis. The presence of spindle cells usually reflects common mesenchymal tumour, yet the diagnosis of synovial sarcoma should also be considered when these cells are observed in gastric tumours and there is a discrepancy between the tumour morphology and the immunohistochemical stain results. The prognosis of these tumours is uncertain, given the rarity of the disease.

\section{Author contributions}

All authors had full access to the data, contributed to the study, approved the final version for publication, and take responsibility for its accuracy and integrity. S Law had the concept of the study, S Law and R Collins acquired the necessary data, all authors analysed and interpreted the data, all authors took part in drafting the manuscript as well as critically revised it for intellectual content.

\section{Conflicts of interest}

All authors have disclosed no conflicts of interest.

\section{Funding/support}

This case report received no specific grant from any funding agency in the public, commercial, or not-for-profit sectors.

\section{Ethics approval}

The patient was treated in accordance with the Declaration of Helsinki. The patient provided informed consent for all procedures.

\section{References}

1. Suurmeijer A, de Bruijn D, Geurts van Kessel A, et al. Synovial sarcoma. In: Fletcher CD, Bridge JA, Hogendoorn P, Mertens F, editors. WHO Classification of Tumours of Soft Tissue and Bone. 4th ed. Lyon: IARC; 2013: 213-5.

2. Weiss SW, Goldblum JR. Malignant soft tissue tumors of uncertain type. In: Weiss SW, Goldblum JR, editors. Enzinger and Weiss's Soft Tissue Tumors. 4th ed. St Louis, MO: Mosby; 2001: 1483-565.

3. Spillane AJ, A'Hern R, Judson IR, Fisher C, Thomas JM. Synovial sarcoma: a clinicopathologic, staging, and prognostic assessment. J Clin Oncol 2000;18:3794-803.

4. Alsharief AN, Fageeh M, Alabdulkarim Y. Monophasic synovial sarcoma presenting as a primary ileal mass: a case report and review of the literature. J Med Case Rep 2012;6:83.

5. Fisher C. Synovial sarcoma. Ann Diagn Pathol 1998;2:40121.

6. McNeill J, Nguyen YV. Synovial sarcoma of the abdominal wall. Radiol Case ReP 2015;2:108.

7. Köse D, Annagür A, Erol C, Uğraş S, Köksal Y. Synovial sarcoma in a premature newborn. Pediatr Int 2014;56:e1720.

8. Billings SD, Meisner LF, Cummings OW, Tejada E. Synovial sarcoma of the upper digestive tract: a report of two cases with demonstration of the $\mathrm{X} ; 18$ translocation by fluorescence in situ hybridization. Mod Pathol 2000;13:68-
76.

9. Makhlouf HR, Ahrens W, Agarwal B, et al. Synovial sarcoma of the stomach: a clinicopathologic, immunohistochemical, and molecular genetic study of 10 cases. Am J Surg Pathol 2008;32:275-81.

10. Fuente I, Bruballa R, Corradetti S, Cavadas D, Beskow A, Wright F. Gastric synovial sarcoma. J Gastrointest Surg 2019;23:1515-7.

11. Crew AJ, Clark J, Fisher C, et al. Fusion of SYT to two genes, SSX1 and SSX2, encoding proteins with homology to the Kruppel-associated box in human synovial sarcoma. EMBO J 1995;14:2333-40.

12. Akhunji S, Musil I, Baisre A, Bhattacharyya A, Cranmer L. Synovial sarcoma arising in the gastric wall: case report and literature review. Cancer Ther 2007;5.

13. Wang CC, Wu MC, Lin MT, Lee JC. Primary gastric synovial sarcoma. J Formos Med Assoc 2012;111:516-20.

14. Sinniah RP, Roche E, Cameron D. GI synovial sarcomas. Clin Transl Gastroenterol 2012;3:e11.

15. Sahara S, Otsuki Y, Egawa Y, et al. Primary synovial sarcoma of the stomach-a case report and review of the literature. Pathol Res Pract 2013;209:745-50.

16. Kamata K, Wada R, Yajima N, Sawada M, Wakasa H, Yagihashi S. Primary gastric synovial sarcoma: molecular diagnosis and prediction of prognosis. Clin J Gastroenterol 2013;6:303-8

17. Torres Rivas HE, Fernández S, Fresno MF. Primary gastric synovial sarcoma. Pathology 2014;46:253-6.

18. Michot N, Robert PE, De Muret A, Marques F, de Calan L, Benchellal Z. Gastric synovial sarcoma: case report and systematic review of literature. J Gastrointest Cancer 2014;45 Suppl 1:129-31.

19. Romeo S, Rossi S, Acosta Marin M, et al. Primary synovial sarcoma (SS) of the digestive system: a molecular and clinicopathological study of fifteen cases. Clin Sarcoma Res 2015;5:7.

20. Wong NA, Campbell F, Shepherd NA. Abdominal monophasic synovial sarcoma is a morphological and immunohistochemical mimic of gastrointestinal stromal tumour. Histopathology 2015;66:974-81.

21. So IT, Cho KB, Lee JY, et al. A primary gastric synovial sarcoma: A case report and literature review. Medicine (Baltimore) 2017;96:e8904.

22. Hu S, Wong K, Ramesh KH, Vilanueva-Siles E, Panarelli $\mathrm{N}$, In H. Diffuse, aggressive metastatic progression after minimally invasive local resection of primary gastric synovial sarcoma: a case report and systematic review of the literature. J Gastrointest Cancer 2019;50:116-22.

23. Olsen G, Beal E, Pfeil S, Dillhoff M. Primary gastric synovial sarcoma mimicking a gastrointestinal stromal tumour (GIST): gastric synovial sarcoma. J Gastrointest Surg 2018;22:1450-1.

24. Tsuji S, Hisaoka M, Morimitsu Y, et al. Detection of SYT-SSX fusion transcripts in synovial sarcoma by reverse transcription-polymerase chain reaction using archival paraffin-embedded tissues. Am J Pathol 1998;153:1807-12.

25. Terry J, Barry TS, Horsman DE, et al. Fluorescence in situ hybridization for the detection of $t(X ; 18)(\mathrm{p} 11.2 ; \mathrm{q} 11.2)$ in a synovial sarcoma tissue microarray using a breakapartstyle probe. Diagn Mol Pathol 2005;14:77-82.

26. Casali PG, Abecassis N, Aro HT, et al. Soft tissue and visceral sarcomas: ESMO-EURACAN Clinical Practice Guidelines for diagnosis, treatment and follow-up. Ann Oncol 2018;29(Suppl 4);iv268-9. 